\title{
INVENTION OF A NEW 718-TYPE Ni-Co SUPERALLOY FAMILY FOR HIGH TEMPERATURE APPLICATIONS AT $750^{\circ} \mathrm{C}$
}

\author{
T. Fedorova ${ }^{1}$, J. Rösler ${ }^{1}$, B. Gehrmann ${ }^{2}$ and J. Klöwer ${ }^{2}$ \\ ${ }^{1}$ Technische Universität Braunschweig, D-38106 Braunschweig ${ }^{2}$ Outokumpu \\ VDM GmbH, D-58791 Werdohl
}

Keywords: Alloy 718, alloy development, microstructural stability, workability

\begin{abstract}
In this paper the development of a new $\gamma^{\prime} \gamma^{\prime \prime}$-alloy on the basis of Alloy718 is presented, where the microstructure is stable at $800^{\circ} \mathrm{C}$, mechanical properties are similar to Alloy 718 , yet do not deteriorate beyond $650^{\circ} \mathrm{C}$, and the forging window is wider than the one of Alloy718, allowing for good workability. This was essentially achieved by the addition of about $17 \%-30 \%$ Co in combination with an $\mathrm{Al} / \mathrm{Ti}$-ratio of more than 5.0 and an Al-content of about $1.6 \%-2.2 \%$. The key role of cobalt is to stabilize the $\delta$ phase, allowing for solvus temperatures in excess of $1100^{\circ} \mathrm{C}$. Consequently, the stability of the $\gamma^{\prime}$-phase can be increased by further addition of aluminum. At the same time the Ti-content is reduced to prevent formation of the $\eta(\mathrm{Ni}, \mathrm{Co})_{3}(\mathrm{Ti}, \mathrm{Al}, \mathrm{Nb})$ phase. Besides discussion of the alloy development concept, information on microstructure evolution and mechanical properties will be given.
\end{abstract}

\section{Introduction}

The past fifteen years have seen increasingly rapid advances in the field of high temperature disk alloys for aircraft engines and stationary gas turbines [1,2]. The main purpose of these advances is the invention of a new alloy which can be used at temperatures of up to $750^{\circ} \mathrm{C}$ and can be processed by normal industrial wrought processes. In most of these studies Alloy 718 has been chosen as the basis alloy because of its excellent combination of mechanical properties, good machinability - especially workability - and relatively low cost. The unique good workability of Alloy 718 is based on the existence of the $\delta-\mathrm{Ni}_{3} \mathrm{Nb}$ phase and on the relatively low solvus temperature of the $\gamma^{\prime}$ phase. These two characteristics make fine grain forging (ASTM 7 and finer) possible. The precipitations of the $\delta$ phase pin the grain boundaries and avoid grain coarsening during forging; for this reason the last forging step of Alloy 718 is usually done at temperatures just below the $\delta$ phase solvus in order to preserve the material's relatively low resistance to deforming [3]. The solvus temperatures of the $\gamma^{\prime \prime}$ and of the $\gamma$ phases are about $920^{\circ} \mathrm{C}$ and about $850^{\circ} \mathrm{C}$, respectively. The main relevant strengthening phase for the workability process is the $\gamma^{\prime}$ phase. Due to coherent precipitation, hardening occurs very quickly while material strength grows rapidly. In this case the alloy needs to undergo a heat treatment at a higher temperature in order to dissolve the precipitated $\gamma^{\prime}$ particles. The temperature range in which fine grain forging is possible between the solvus temperature of the $\delta$ phase $\left(\mathrm{T}_{\delta, \mathrm{s}}\right)$ and the solvus temperature of the $\gamma^{\prime}$ phase $\left(\mathrm{T}_{\gamma^{\prime}, \mathrm{s}}\right)$ is called the forging window $\left(\mathrm{T}_{\delta}-\mathrm{T}_{\hat{\gamma}, \mathrm{s}}\right)$. Within this range grain coarsening is still avoided but the material's resistance to deformation is low enough for forging. The forging window of Alloy 718 has a range of about $180^{\circ} \mathrm{C}$.

However, Alloy 718 can only be used at temperatures up to $650^{\circ} \mathrm{C}$ due to its microstructural instability. The metastable $\gamma^{\prime \prime}$ phase overages rapidly and transforms to the incoherent thermodynamically stable $\delta$ phase at temperatures of about $650^{\circ} \mathrm{C}$ and above. In doing so, the 
alloy loses its strength and ductility because of the formation of the plate-like $\delta$ phase particles in the grain at the cost of the strengthening $\gamma^{\prime \prime}$ phase.

The most established way of stabilizing the microstructure in the alloys is by increasing the amount of the $\gamma^{\prime}$ phase and by foregoing the $\gamma^{\prime \prime}$ phase. For applications at temperatures of 700$750^{\circ} \mathrm{C}$, Waspaloy is usually used and ATI 718 Plus ${ }^{\circledR}$ is a possible candidate under consideration. These two alloys have an increased amount of $\gamma^{\prime}$ phase which allows their use at higher temperatures than Alloy $718[4,5]$. In ATI 718Plus ${ }^{\circledR}$ the $\delta$ and $\eta$ phases $[6,7,8]$ can precipitate on the grain boundaries similar to Alloy 718 to control the grain coarsening.

However, increasing the amount of the $\gamma^{\prime}$ phase increases its precipitation kinetics and the solvus temperature to about $950^{\circ} \mathrm{C}$ in ATI 718Plus ${ }^{\circledR}$ [7]. This reduces the forging window to around $80^{\circ} \mathrm{C}$ because the solvus temperature of the $\delta$ phase remains constant. With the decrease of the forging window the forging process becomes more complex because the material needs to be tempered more often and, especially in large forging, it becomes more and more difficult to keep the material temperature uniform within the forging window.

In Waspaloy, the amount of the $\dot{\gamma}$ phase is raised even further and thus the solvus temperature of the $\gamma$ is about $1030^{\circ} \mathrm{C}$. Furthermore, $\mathrm{M}_{23} \mathrm{C}_{6}$ carbides are used as the second high temperature phase for pinning grain boundaries. However, the solvus temperature of $\mathrm{M}_{23} \mathrm{C}_{6}$ carbides is about $1030-1040^{\circ} \mathrm{C}$ and consequently, Waspaloy does not really have a fine-grain forging window [9]. For this reason, it is not possible to achieve similarly fine grains as in Alloy 718. Furthermore, its processing costs are much higher than Alloy $718 \mathrm{~s}$, because the alloy needs much more effort with respect to the forging processes and heat treatments.

The most common alloys for application as disk materials at a maximum temperature of $750^{\circ} \mathrm{C}$ are $\mathrm{U} 720 \mathrm{Li}$, Rene $95, \mathrm{RR} 1000$ and $\mathrm{ME} 3[10,11]$. All of these alloys are pure $\gamma^{\prime}$ strengthening alloys. The increased volume fraction, combined with a higher content of refractory elements, has caused challenges in the manufacturing process because of segregation; and in hot workability because of the high solvus temperature and the precipitation kinetics of the $\gamma^{\prime}$ phase. U720Li can be produced using a cast - wrought process; Rene 95, RR1000 and ME3 are produced using a powder metallurgy (PM) process. PM processing requires extremely clean powder source material as well as expensive thermomechanical production steps. All of this limits the PM produced disk alloys to special, higher cost applications.

The aim of this research is the development of a new design concept for a nickel-based wrought superalloy family for high temperature applications in aero engines and stationary gas turbines requiring a maximum temperature of $750^{\circ} \mathrm{C}$. The wrought properties of the new materials should be comparable to Alloy 718, so that fine grain forging is possible. The current work focuses on the development concept supported by experimental work. The influence of $\mathrm{Co}, \mathrm{Al}$ and $\mathrm{Ti}$ on the microstructure and the microstructural stability of alloys at temperatures of $700^{\circ} \mathrm{C}$ and $800^{\circ} \mathrm{C}$ up to $2000 \mathrm{~h}$ were studied.

\section{Experimental Procedures}

ThermoCalc software was used in order to predict the phases and their solvus temperatures in the new alloys. More than 50 different alloys were produced and used to experimentally study the effects of various elements on microstructure, forging, mechanical properties, and microstructural stability at higher temperatures. Most alloys presented in this paper 
(laboratory scale) were made by plasma arc melting, followed by casting the material into a water-cooled copper crucible. These alloys were deformed by rotary swaging of round bars from $13 \mathrm{~mm}$ to $9 \mathrm{~mm}$ in diameter at a temperature of $1075^{\circ} \mathrm{C}$. Like Alloy 718 , some alloys (pilot plant scale) were produced by triple melting, i.e. Vacuum Induction Melting (VIM) + Electroslag Rapid Remelting (ESR) + Vacuum Arc Remelting (VAR). The ingot dimensions after the primary VIM step are $200 \mathrm{~mm}$ in diameter and approx. $650 \mathrm{~mm}$ in length. Forging was done similarly to standard Alloy 718. After wrought processing, all alloys were solution annealed at $980^{\circ} \mathrm{C} / 1.5 \mathrm{~h}$, followed by water cooling to room temperature (RT). All alloys were then double aged as standard Alloy $718\left(721^{\circ} \mathrm{C} / 8 \mathrm{~h}+\right.$ furnace cooled at $50^{\circ} \mathrm{C} / \mathrm{h}+$ $620^{\circ} \mathrm{C} / 8 \mathrm{~h}$ air cooled to RT) to allow for comparison with Alloy 718 at identical heat treatment conditions. For the examination of long term microstructural stability of the material, the heat treatments were conducted at a temperature of $700^{\circ} \mathrm{C}$ for $500 \mathrm{~h}$ and at $800^{\circ} \mathrm{C}$ for $500 \mathrm{~h}$ and $2000 \mathrm{~h}$.

For microstructural analysis by scanning electron microscopy (SEM) the samples were mechanically polished and etched. V2A-stain etching media was used in this study. The media etches the matrix whereas all precipitates remain unaffected and grain boundaries visible. The chemical composition of $\mathrm{V} 2 \mathrm{~A}$-stain is $200 \mathrm{ml} \mathrm{H}_{2} \mathrm{O}, 200 \mathrm{ml} \mathrm{HCl}, 20 \mathrm{ml} \mathrm{HNO}_{3}$ and $0.6 \mathrm{ml}$ "Vogels Sparbeize“. SEM was used to observe the morphology and distribution of all the phases. EDX was used to identify precipitated phase.

\section{Alloy Design}

The new alloys have been designed to be (i) processed by normal industrial wrought processes and (ii) have superior microstructural stability at temperatures of up to $750^{\circ} \mathrm{C}$. In order to achieve (ii) the solvus temperature of the $\gamma^{\prime}$ phase must be increased so that volume fraction increases as well. This is achieved by increasing the $\mathrm{Al}, \mathrm{Ti}$ and $\mathrm{Nb}$ amounts in the material. However, a study by Cozar and Pineau reports that $(\mathrm{Al}+\mathrm{Ti}+\mathrm{Nb})$ content should be lower than 7.5 at. $\%[12,13]$ because of processing considerations.

All alloys with a higher $(\mathrm{Al}+\mathrm{Ti}+\mathrm{Nb})$ content had problems during forging. Furthermore, the $\mathrm{Nb}$ content $(5.4 \mathrm{wt} . \%$ ) cannot be raised because of a tendency toward segregation during the melting and remelting processes with the resulting precipitation of brittle Laves phase, which is not acceptable in the $\mathrm{Ni}$ based superalloys. The study by Cao and Kennedy on the development of ATI 718Plus ${ }^{\circledR}$ to date has tended to focus on $(\mathrm{Al}+\mathrm{Ti})[4,5]$ content. They limited the $(\mathrm{Al}+\mathrm{Ti})$ content to 4.0 at. $\%$ and studied different $\mathrm{Al} / \mathrm{Ti}$ (at.\%) ratios. The best combination of mechanical properties and microstructural stability at temperatures of up to $704^{\circ} \mathrm{C}$ in ATI 718 Plus ${ }^{\circledR}$ was observed at an $\mathrm{Al} / \mathrm{Ti}$ ratio of about 4.

However, not only the $(\mathrm{Al}+\mathrm{Ti})$ content must be defined, but the highest $\gamma^{\prime}$ solvus temperature acceptable for forging as well: it must be lower than $1030^{\circ} \mathrm{C}$ because otherwise forging would be as difficult as in the case of Waspaloy. Increasing the amount of the $\gamma^{\prime}$ phase at constant $\mathrm{Nb}$ content particularly reduces the forging window because the $\gamma^{\prime}$ solvus rises but the $\delta$ solvus is still constant at the same time.

In order to be processed by normal industrial wrought processes the forging window must be about $100^{\circ} \mathrm{C}$ and the precipitation kinetics of the $\gamma^{\prime}$ phase has to be slower than in Waspaloy. The new materials should be free from brittle phases such as Laves or $\sigma$ phases, and the microstructure of a new alloy must be stable after a long term heat treatment at a temperature of $800^{\circ} \mathrm{C}$ for $500 \mathrm{~h}$. 
In many studies Cobalt was alloyed to decrease the $\gamma^{\prime}$ phase solvus temperature $[14,15]$, and for this reason, Co was included in this study. Because Fe is usually responsible for the precipitation of the Laves phase in Alloy 718 it was initially excluded in order to destabilize the Laves phase in the alloys and the Ni content was balanced. Increasing the Co content to up to $15 \mathrm{wt}$ \% during this study in Alloy 718 (without Fe content) the solvus temperature of the $\delta$ phase unexpectedly rose by around $50^{\circ} \mathrm{C}$ and the further raising of Co content in material stabilizes the $\delta$ phase to such an extent that even primary precipitation from the melt may occur. Fig. la shows the thermodynamic prediction of the solvus temperatures for the solid phases and the solidus temperature for alloys with a continuously changing concentration of Co. The Co concentration was varied from 0 wt.\% to $50 \mathrm{wt} \%$. The $\mathrm{Ni}$ concentration was balanced; the other elements stayed constant as in standard Alloy 718. It can be seen that Co also stabilizes the $\eta$ phase. If at $10 \mathrm{wt} \% \mathrm{Co}$ the $\eta$ phase is stable in the small temperature range between $820^{\circ} \mathrm{C}$ and $750^{\circ} \mathrm{C}$, at $30 \mathrm{wt} . \% \mathrm{Co}$ the $\eta$ phase will be stable at $1000^{\circ} \mathrm{C}$ and below. The $\gamma^{\prime}$ phase will be destabilized with this precipitation of $\eta$ phase because the $\eta$ phase absorbs Ti and Al. Furthermore, the $\eta$ phase is stable at higher temperatures than $\gamma^{\prime}$ phase. The solvus temperature and stability range of the $\sigma$ phase also rises with an increasing Co concentration in the material.

For examination of the stabilizing effect of cobalt on the $\delta$ phase, the alloys L4 (Ni17\%Co - 19\%Cr-2.9\%Mo-5.4\%Nb-1.1\%Ti-1.2\%Al), L17 (Ni-25\%Co-19\%Cr-2.9\%Mo $5.4 \% \mathrm{Nb}-1.1 \% \mathrm{Ti}-1.2 \% \mathrm{Al}$ ) and L18 (Ni-30\%Co-19\%Cr-2.9\%Mo-5.4\% Nb-1.1\% Ti-1.2\%Al) can be viewed. Figure $1 \mathrm{~b}$ shows the quasi-binary Ni-Co diagram based on alloy L4. The Ti and $\mathrm{Al}$ contents were constant and are $1.1 \mathrm{wt} \%$ and $1.2 \mathrm{wt} \%$, respectively. The solvus temperature of the $\delta$ phase increase significantly with the addition of Co to the alloy.

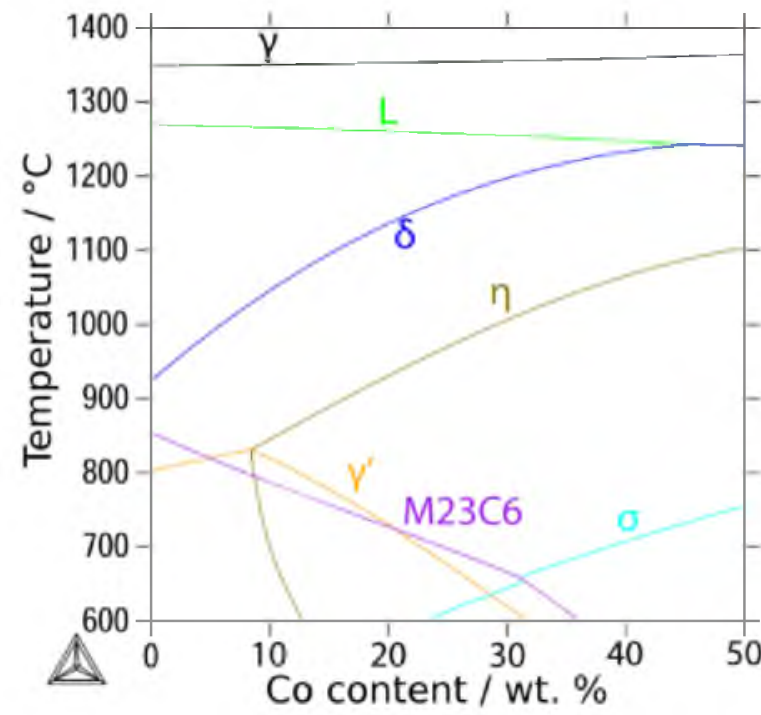

(a)

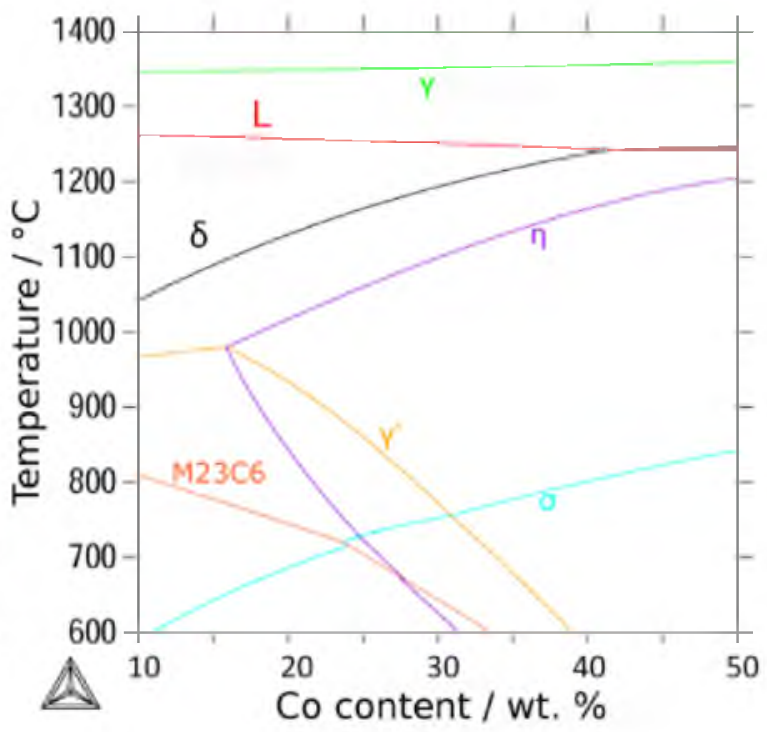

(b)

Figure 1 Quasi-binary Ni-Co diagram (a) based on Alloy 718 without Fe (Ni is replaced by $\mathrm{Co}$ ) and (b) based on alloy $\mathrm{L} 4$ ( $\mathrm{Ni}$ is replaced by $\mathrm{Co}$ ) 
The stability of the $\eta$ phase rises with the increasing Co content. Figure 2 a-c show the microstructure of alloys L4 with 17 wt.\% Co, L17 with 25 wt.\% Co and L18 with 30 wt.\% Co (laboratory scale) after standard double aged heat treatment. It can be clearly seen that by increasing the Co content the amount of $\delta$ phase grew significantly. The precipitates occurred at grain boundaries as well as in the grains. Furthermore, the $\eta$ phase can also be identified in the grains in alloys L17 and L18 with $25 \mathrm{wt} \% \mathrm{Co}$ and $30 \mathrm{wt} \% \mathrm{Co}$, respectively. These observations are consistent with the ThermoCalc simulations that can be seen in Figure 3.

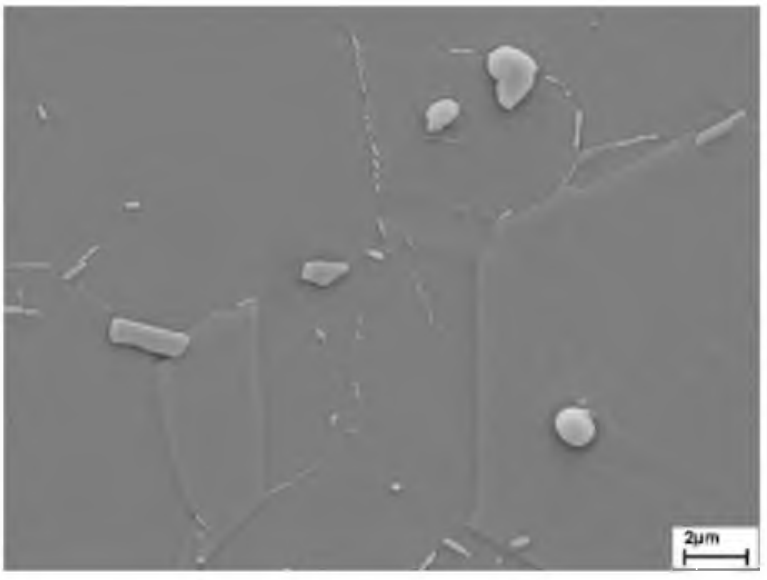

(a)

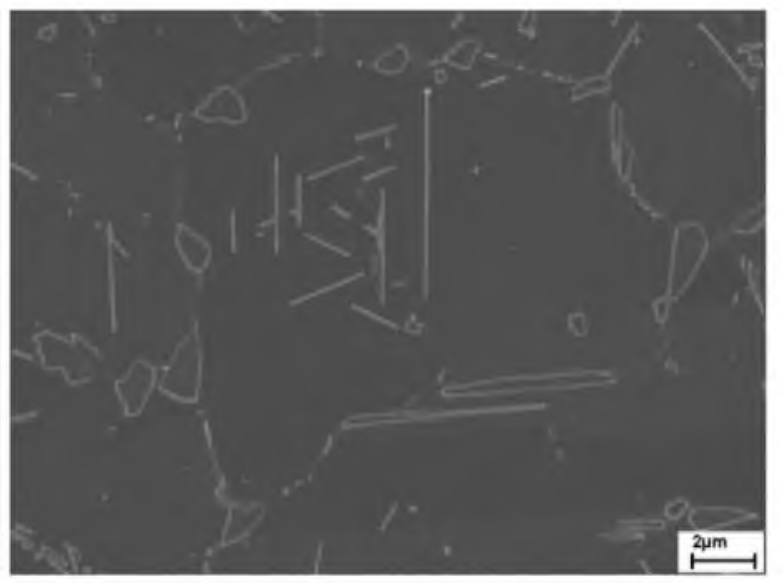

(b)

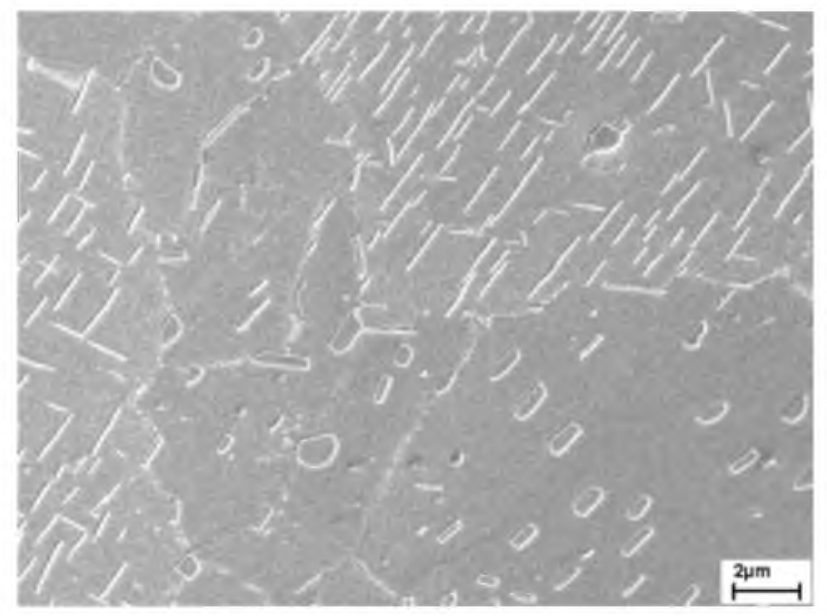

(c)

Figure 2. Microstructure of alloys (a) L4 (17 wt.\% Co), (b) L17 (25 wt.\% Co) and (c) L18 (30 wt. \% Co) (laboratory scale) after standard precipitation heat treatment

During this study the Co range used was mostly between $17 \mathrm{wt} \%$ and $32 \mathrm{wt} \%$. The Co content has to be adjusted to the $\mathrm{Ti}$ and $\mathrm{Al}$ content to balance the interaction between element content and precipitated phases such as $\delta, \eta$ and $\gamma^{\prime}$ phase.

In Figure 3 the $\gamma^{\prime}$ phase solvus temperature of experimental alloys in dependence on $(\mathrm{Al}+\mathrm{Ti})$ content is presented. In order to fix the solvus temperature of this phase between $900^{\circ} \mathrm{C}$ and $1030^{\circ} \mathrm{C}$ (horizontal lines), a (Al+Ti) content between 3 at.\% and 5.6 at.\% (vertical 
lines) was chosen. The most interesting alloys for this study have a ( $\mathrm{Al}+\mathrm{Ti})$ content between 3.7 at. $\%$ and 4.7 at. $\%$ and as a result the $\gamma$ phase solvus temperature is situated between $940^{\circ} \mathrm{C}$ and $1000^{\circ} \mathrm{C}$. In order to produce a new alloy by normal industrial wrought processes, the forging window should be about $100^{\circ} \mathrm{C}$ to allow fine grain size forging. For this purpose, the Co content must be adjusted accordingly. In Figure 4, the forging window of experimental alloys as a function of different $\mathrm{Co}$ and $(\mathrm{Al}+\mathrm{Ti})$ contents is presented. The vertical lines at 3 at. $\%$ and 5.6 at. $\%$ were taken from Figure 3. In addition, vertical boundary lines at 3.7 at. $\%$ and 4.7 at.\% limit the generally optimum (A1+Ti) content in new alloys. The horizontal line at $80^{\circ} \mathrm{C}$ indicates the minimum forging window of new alloys. The horizontal line at $140^{\circ} \mathrm{C}$ indicates the optimum forging window. It is clearly recognizable that the forging window decreases with increasing $(\mathrm{Al}+\mathrm{Ti}$ ) content but increases with the amount of Co content.

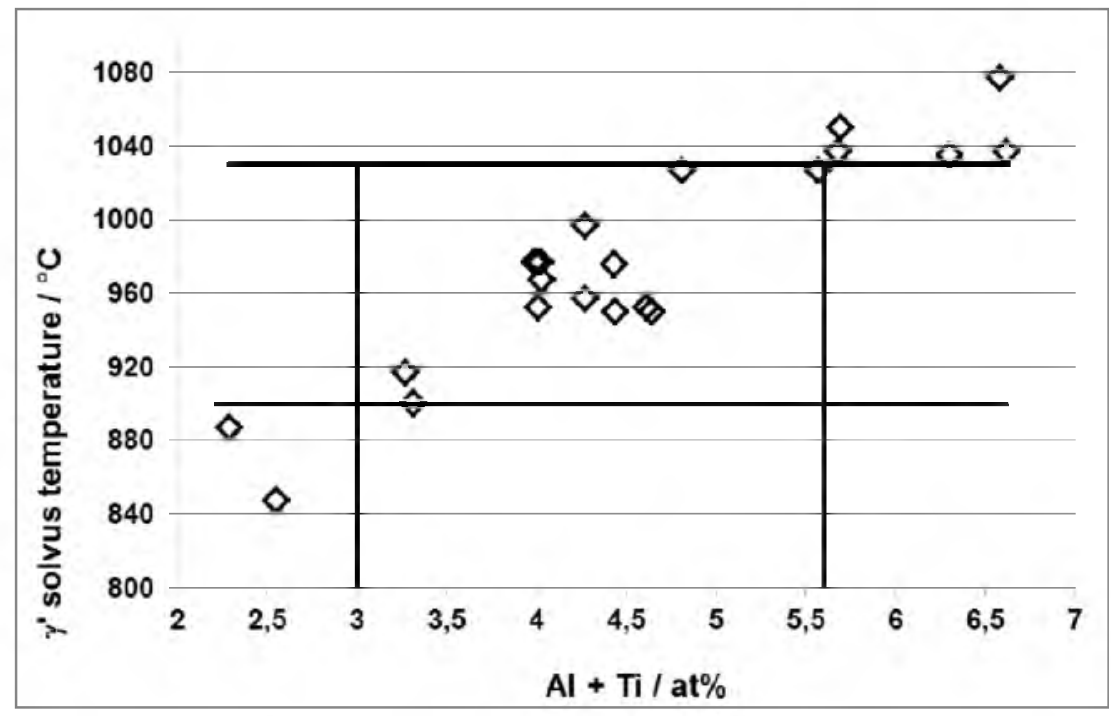

Figure 3. The variation of $\gamma^{\prime}$ phase solvus temperature in experimental alloys is dependent on $(\mathrm{Al}+\mathrm{Ti})$ content.

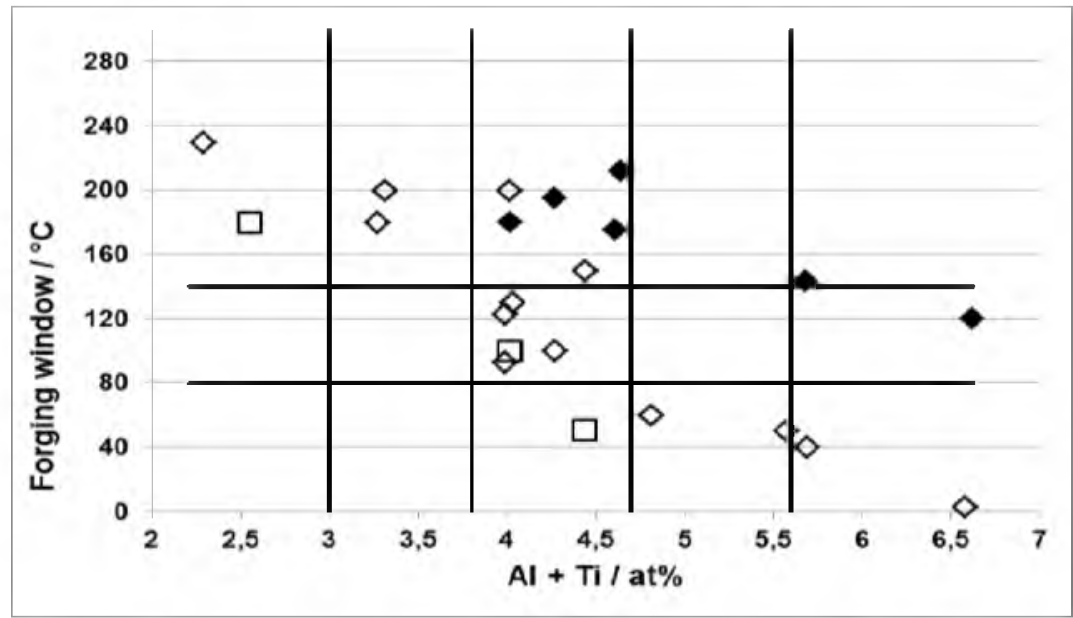

Figure 4. The forging window $\left(\mathrm{T}_{\delta, \mathrm{s}}-\mathrm{T}_{\gamma^{\prime}, \mathrm{s}}\right)$ of experimental alloys depends on $\mathrm{Co}$ and (Al+Ti) contents; Co content: square- up to 11.5 at. $\%$, white rhomb 11.5 at. $\% \leq \mathrm{Co} \leq 18$ at. $\%$, black rhomb- more than 18 at. \% 
However, the precipitation of the $\eta$ phase with the increasing Co content was predicted in 718 type alloys. The stability of the $\eta$ phase can be influenced by the Ti content in the material. For this reason, not only the $(\mathrm{Al}+\mathrm{Ti})$ content must be defined, but the $\mathrm{Al} / \mathrm{Ti}$ ratio as well. The $\mathrm{Ti}$ content must be reduced when increasing the Co content in order to destabilise the precipitation of the $\eta$ phase. However, decreasing the Ti content destabilises the $\gamma^{\prime}$ phase, too. Thus, the Al content has to be raised, but in such a way that the $\gamma$ solvus is still lower than $1030^{\circ} \mathrm{C}$. For instance, in Figure 5 the quasi-binary Ni-Ti diagram with fixed $\mathrm{Co}(17 \mathrm{wt} . \%), \mathrm{Al}$ (2 wt.\%), Nb (5.4 wt.\%), Mo (2.96 wt.\%), Cr (18.9 wt.\%) and C (0.025 wt.\%) content is presented. Two important parameters can be seen in this diagram: the changing size of the forging window by stabilizing the $\gamma^{\prime}$ phase and the correlation between Ti content and precipitation of the $\eta$ phase.

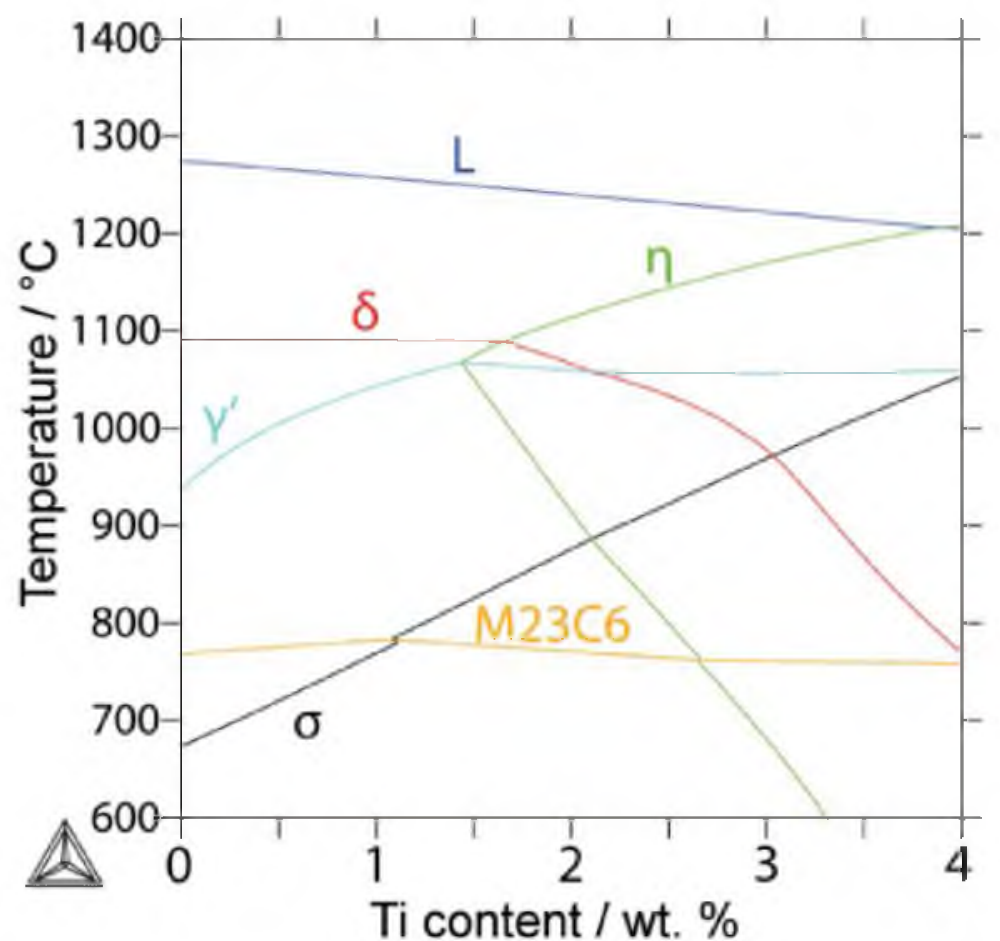

Figure 5. Quasi-binary Ni-Ti diagram with 17 wt.\% Co, 2 wt.\% Al, 5.4 wt.\% Nb, 2.96 wt.\% Mo, 18.9 wt. $\% \mathrm{Cr}$ and $0.025 \mathrm{wt} . \% \mathrm{C}$ (Ni is replaced by $\mathrm{Ti}$ )

\section{Experimental results}

Based on the experimental results from the laboratory scale trials, alloy L4 (Ni-17\%Co$19 \% \mathrm{Cr}-2.9 \% \mathrm{Mo}-5.4 \% \mathrm{Nb}-1.1 \% \mathrm{Ti}-1.2 \% \mathrm{Al}$ ) was produced at pilot plant scale during this study. Because of the $17 \mathrm{wt} . \% \mathrm{Co}$ the $\delta$ phase solvus temperature increased by about $50^{\circ} \mathrm{C}$ to about $1080^{\circ} \mathrm{C}$. The higher content of $\mathrm{Ti}$ and $\mathrm{Al}$ influences the $\gamma^{\prime}$ solvus temperature. A small stability range of the $\eta$ phase with a volume fraction of less than $3 \%$ was predicted by ThermoCalc in the temperature range between $940^{\circ} \mathrm{C}$ and $980^{\circ} \mathrm{C}$ (see Figurelb). The same forging process as for Alloy 718 was used. The billets showed no evidence of forging cracks, which suggests that alloy L4 has good formability. Figure 6 shows the typical microstructure of the as-forged billet at mid-radius location $25 \mathrm{~mm}$ from the surface. The microstructure is 
homogeneous and fully recrystallized with a grain size average of ASTM 9. The amount of the $\delta$ phase rose as expected because of the increasing stability of the $\delta$ phase. The following production of pancakes proved this, too. Namely, the pancakes produced at $1000^{\circ} \mathrm{C}$ have a homogeneous microstructure with a grain size average of ASTM 12. The forging of pancakes at $1100^{\circ} \mathrm{C}$ causes a larger grain size average of ASTM 8. This can be explained by the partial dissolution of the $\delta$ phase at $1100^{\circ} \mathrm{C}$.
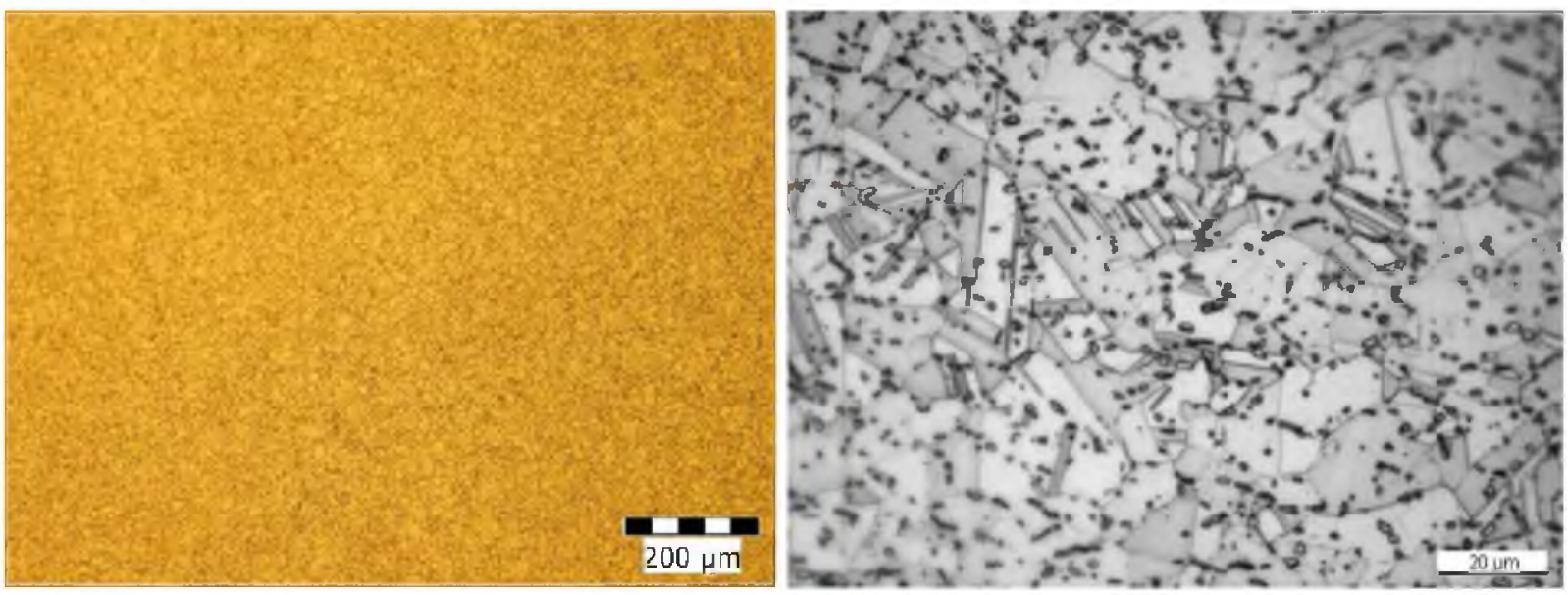

Figure 6. Microstructure of alloy L4 (billet) as-forged $25 \mathrm{~mm}$ from the surface

These observations confirm that the $\delta$ solvus of alloy L4 was shifted to a higher temperature by about $80^{\circ} \mathrm{C}$ and the solvus temperature of the $\gamma^{\prime}$ phase can be increased without reducing the forging window.

Alloy L4 has good microstructural stability at temperatures of up to $710^{\circ} \mathrm{C}$. Figure 7 shows the microstructure of alloy L4 (pilot plant scale) after standard precipitation heat treatment and the microstructure of L4 and Alloy 718 (both at laboratory scale) after longtime heat treatment at $700^{\circ} \mathrm{C} / 500 \mathrm{~h}$. After standard precipitation as well as after long-time heat treatment at $700^{\circ} \mathrm{C} / 500 \mathrm{~h}$ the microstructure is still stable. The particles of the $\delta$ phase are dispersed just on the grain boundaries. At the same time, Alloy 718 changed significantly after heat treatment at $700^{\circ} \mathrm{C} / 500 \mathrm{~h}$ : the coarsening of $\gamma^{\prime} / \gamma^{\prime \prime}$ and the precipitation of the platelike $\delta$ phase in the grains can be observed.

However, increasing the temperature up to $800^{\circ} \mathrm{C}$ influences the microstructure of alloy L4 significantly: the plate-like $\eta$ phase precipitates in the grains and the precipitates of $\gamma^{\prime} / \gamma^{\prime \prime}$ can be seen (Figure 8). It can be explained by the low Al/Ti ratio of 2.0 (at.\%). In order to achieve an $\eta$ phase free microstructure at temperatures of up to $800^{\circ} \mathrm{C} / 500 \mathrm{~h}$, the $\mathrm{Al} / \mathrm{Ti}$ ratio must be adjusted. 

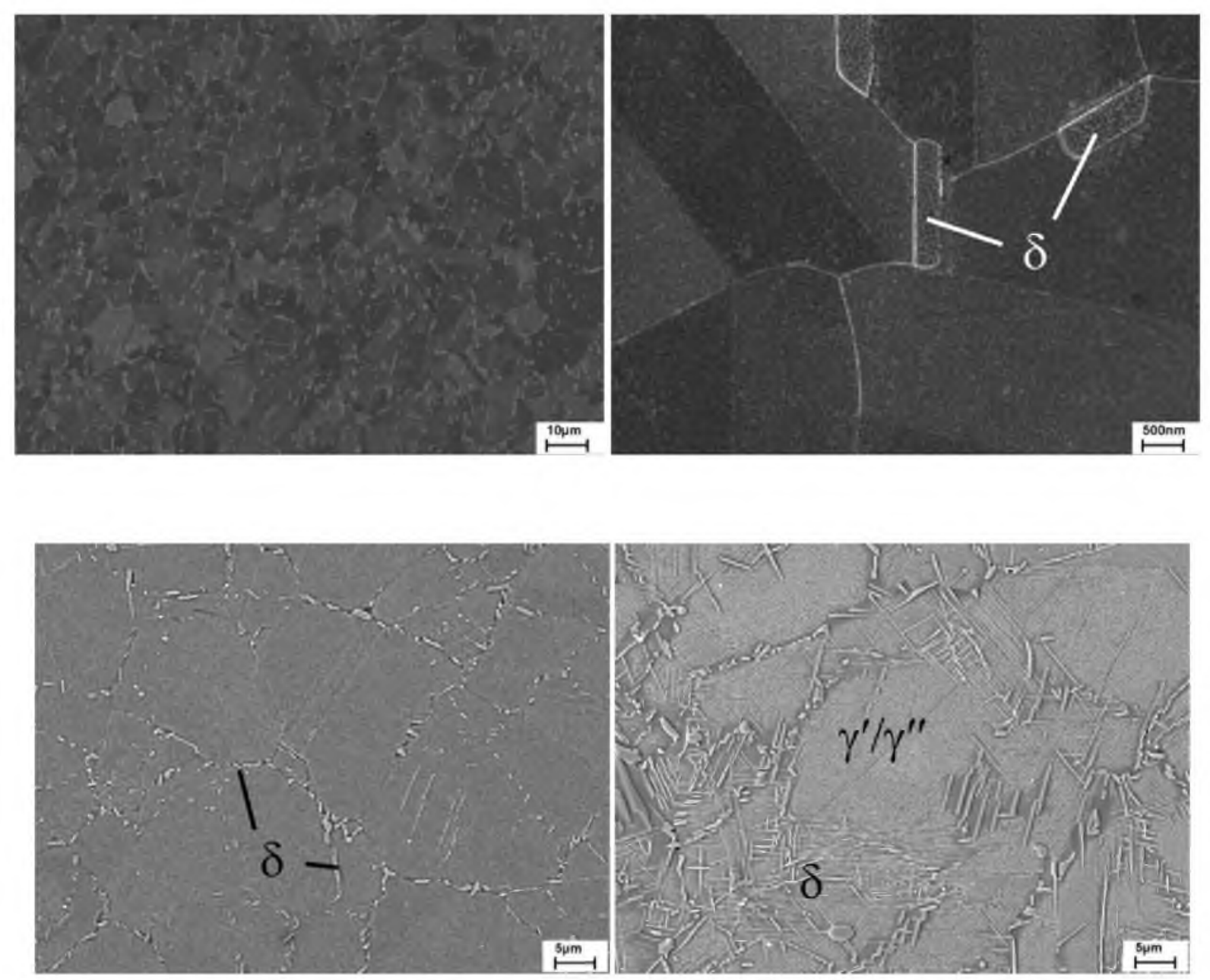

(c)

(d)

Figure 7. Microstructure of (a-b) alloy L4 (billet, pilot plant scale) after standard precipitation heat treatment, (c) alloy L4 and (d) Alloy 718 (both laboratory scale) after heat treatment: $700^{\circ} \mathrm{C} / 500 \mathrm{~h}[16]$

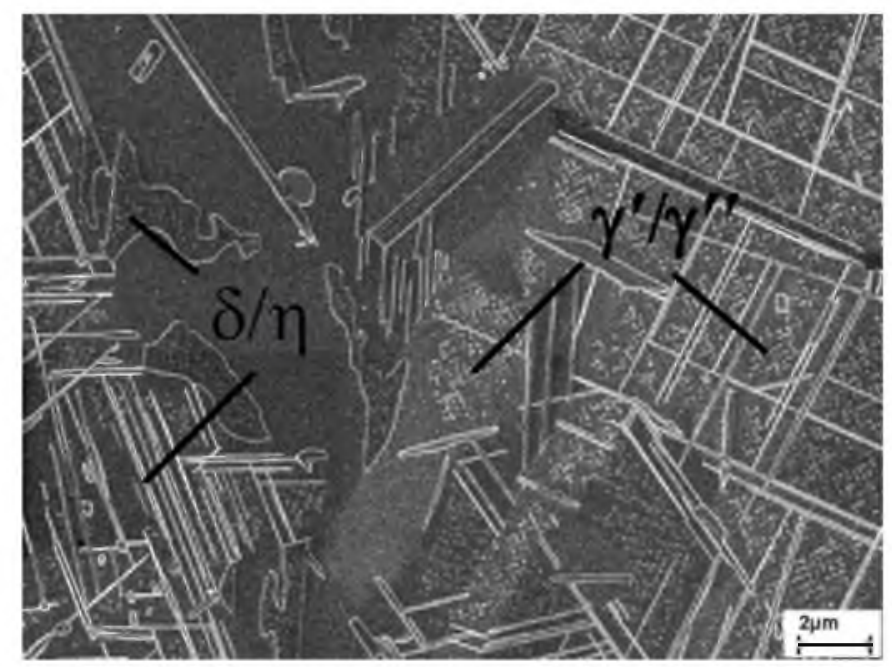

Figure 8. Microstructure of alloy L4 (laboratory scale) after heat treatment: $800^{\circ} \mathrm{C} / 500 \mathrm{~h}$ 
For this reason, the alloys V11 (Ni-30\%Co-19\%Cr-2.9\%Mo-5.4\%Nb-1.1\%Ti-2.0\%Al), V13 (Ni-17\%Co-19\%Cr-2.9\%Mo-5.4\%Nb-0.5\%Ti-2.0\%Al), V16 (Ni-17\%Co-19\%Cr-2.9\%Mo$5.4 \% \mathrm{Nb}-\mathbf{0 . 2} \% \mathrm{Ti}-2.0 \% \mathrm{Al}$ ) and $\mathrm{V} 17$ (Ni-25\%Co-19\%Cr-2.9\%Mo-5.4\%Nb-0.2\% Ti-2.0\%Al) were chosen as an example for this paper. Table I shows the contents of $\mathrm{Co}, \mathrm{Al}, \mathrm{Ti}$, the sum of $(\mathrm{Al}+\mathrm{Ti})$ and $(\mathrm{Al} / \mathrm{Ti})$ ratio all in at.\%. In order to stabilize the $\delta$ phase and achieve microstructural stability at temperatures of up to $800^{\circ} \mathrm{C} / 500 \mathrm{~h}$ the Co content must be raised and the Ti content reduced. Only alloy V11 has a plate-like $\eta$ phase after long-term heat treatment at $800^{\circ} \mathrm{C} / 500 \mathrm{~h}$ (see Figure $9 \mathrm{a}$ ). The reduction in $\mathrm{Ti}$ content makes possible an $\eta$ phase free microstructure after the same heat treatment (see Figure 9b-9d). Furthermore, alloy V17 with $0.2 \mathrm{wt} . \% \mathrm{Ti}$ and $25 \mathrm{wt} . \%$ Co shows an increased forging window which may provide the improved workability and an excellent combination of microstructural stability at $800^{\circ} \mathrm{C}$ up to $2000 \mathrm{~h}$ (see Figure 10 ) and mechanical properties at higher temperatures. For this combination of properties, alloy V17 (VDM Alloy 780 Premium) was selected from these detailed studies for a $20 \mathrm{t}$ triple-melt production. Figure 11 presents the $200 \mathrm{~mm}$ (8inch)' diameter forged billet directly after the forging process, using parameters similar to those for Alloy 718. The billet surface is free of cracks. In comparison to Alloy 718, the new alloy shows improved tensile properties at $750^{\circ} \mathrm{C}\left(\mathrm{R}_{\mathrm{p} 0,2}: 910-940 \mathrm{MPa}, \mathrm{R}_{\mathrm{m}}: 1050-1100 \mathrm{MPa}\right)$ and better creep properties at $700^{\circ} \mathrm{C}$.

Table I. Co, Al and Ti content of the Alloys V11, V13, V16 and V17 all in at.\%.

\begin{tabular}{|l|c|c|c|c|c|c|}
\hline Alloy & Co & $\mathrm{Al}$ & $\mathrm{Ti}$ & $(\mathrm{Al}+\mathrm{Ti})$ & $(\mathrm{Al} / \mathrm{Ti})$ & $\eta$ Phase \\
\hline V11 & 29.4 & 4.34 & 1.34 & 5.56 & 3.24 & stable \\
\hline V13 & 16.6 & 4.22 & 0.59 & 4.81 & 7.15 & - \\
\hline V16 & 16.9 & 4.07 & 0.20 & 4.27 & 20.35 & - \\
\hline V17 & 24.5 & 4.07 & 0.20 & 4.27 & 20.35 & - \\
\hline
\end{tabular}




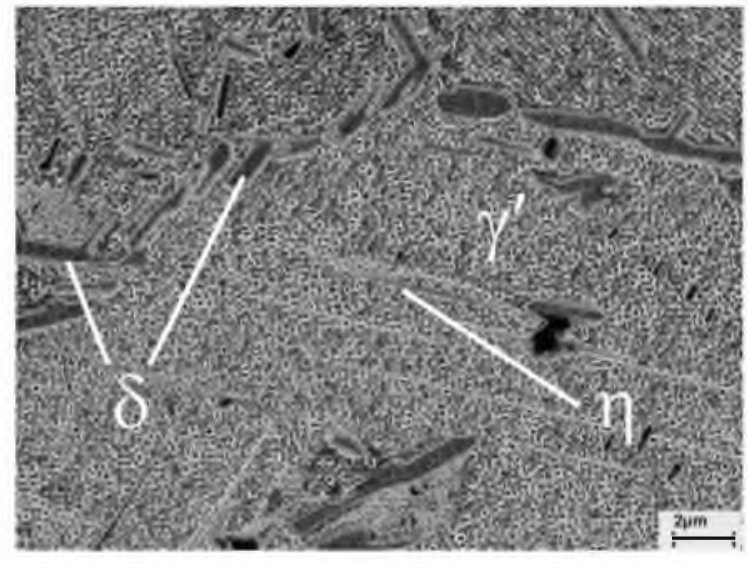

(a) V11

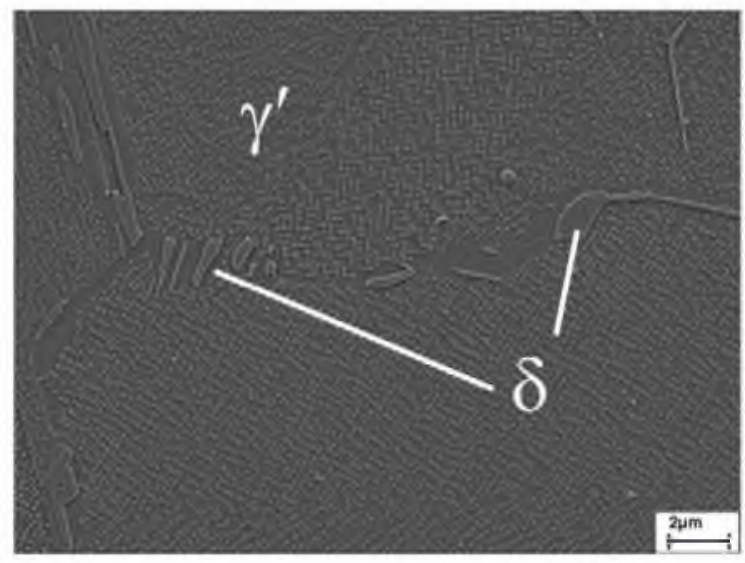

(b) V16

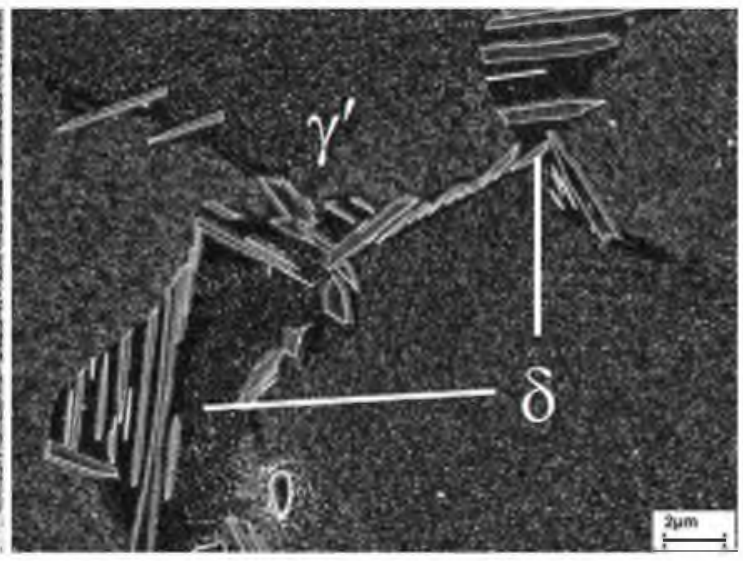

(b) V13

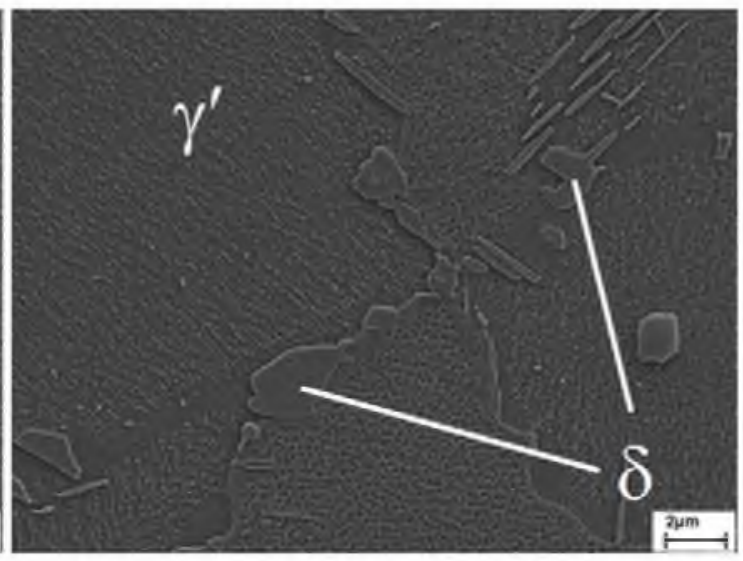

(d) $\mathrm{V} 17$

Figure 9. Microstructure of alloy V11 (a), V13 (b), V16 (c) and V17 (d) (laboratory scale) after heat treatment: $800^{\circ} \mathrm{C} / 500 \mathrm{~h}$
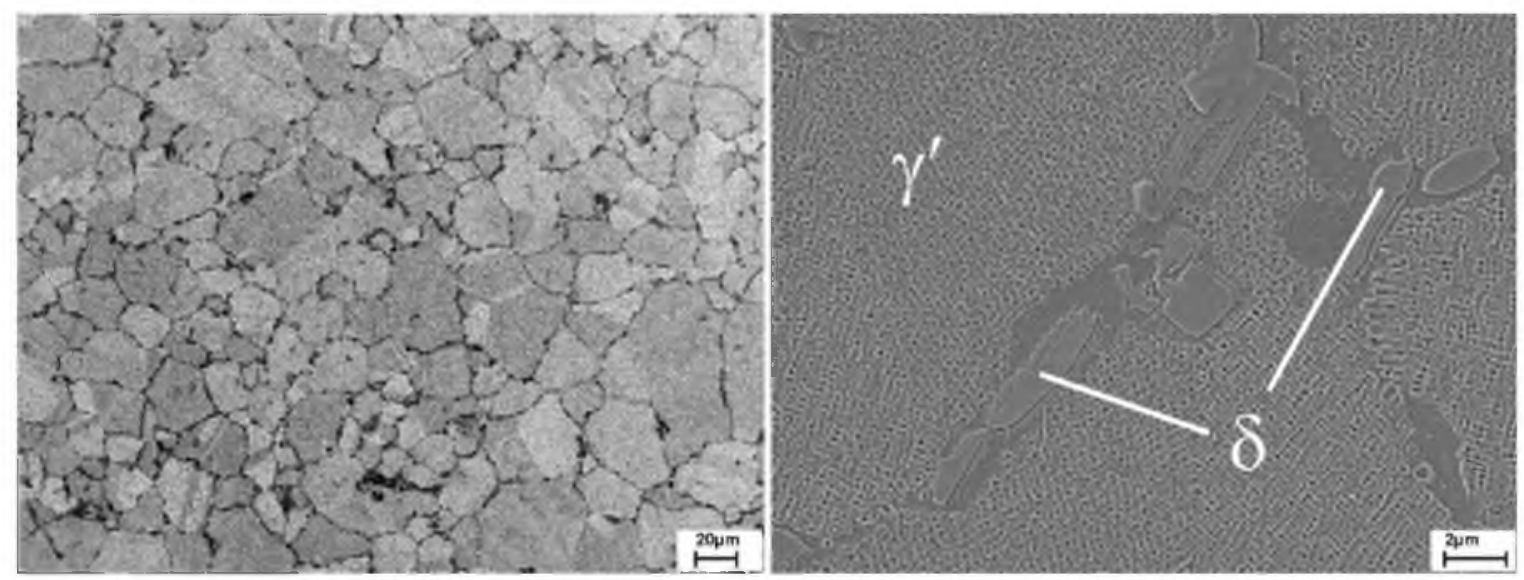

Figure 10. Microstructure of alloy V17 (laboratory scale) after heat treatment: $800^{\circ} \mathrm{C} / 2000 \mathrm{~h}$ 


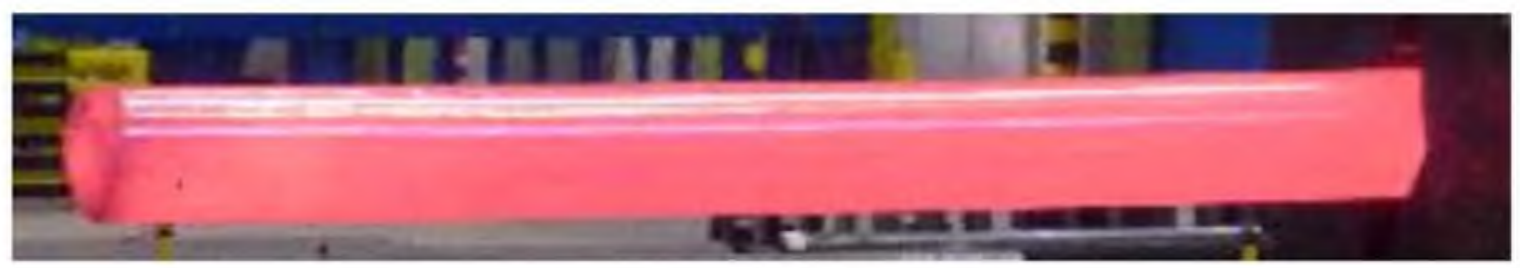

Figure 11.200mm (8inch) forged billet of the new VDM Alloy 780 Premium (V17) using forging parameters similar to those for Alloy 718

\section{Summary and Conclusions}

The role of the alloying elements $\mathrm{Al}$, Ti and especially $\mathrm{Co}$ in 718-type alloys was studied using thermodynamic simulations and experimental evaluations with the objective of designing a new alloy family that (i) can be processed by normal industrial wrought processes and (ii) has superior microstructural stability at temperatures of up to $750^{\circ} \mathrm{C}$. From the study the authors conclude that:

- A new superalloy family was developed during this research. These alloys potentially have a forging window comparable to Alloy 718 , but superior microstructural stability at temperatures of up to $800^{\circ} \mathrm{C}$ and thus allow for significantly higher service temperatures.

- The addition of $15 \mathrm{wt} . \%$ Co and more to 718-type alloys significantly stabilizes the $\delta$ phase. This property of cobalt was used to ensure good workability in the new alloys; the ideal Co range was defined between 17 to $32 \mathrm{wt} . \%$.

- Due to Co addition, the solvus temperature of the $\gamma^{\prime}$ phase can be raised accordingly by a larger content of the $\psi$ forming elements without compromising the forging window. However, it is necessary to select a high $\mathrm{Al} / \mathrm{Ti}$ ratio at the same time.

- Co and Ti stabilize the $\eta$ phase alike, even though the effect of Ti is much more pronounced. Thus, it is essential to increase the $\mathrm{Al} / \mathrm{Ti}$ ratio to insure improved microstructural stability

- The best combination of thermal stability and mechanical properties occurred at an ( $\mathrm{Al}+\mathrm{Ti}$ ) level of about 4.2 to 4.8 at.\% and an $\mathrm{Al} / \mathrm{Ti}$ (at.\%) ratio of more than 7. In order to achieve microstructural stability even at $800^{\circ} \mathrm{C}$ the $\mathrm{Al} / \mathrm{Ti}$ (at.\%) ratio must be elevated to 15 or higher.

- A new alloy VDM Alloy 780 Premium (V17) was selected from these detailed studies and is actually in production starting with a $20 \mathrm{t}$ primary VIM melt to produce VAR-ingots that will be forged into billets

\section{References}

1. X. Xie, J. Dong, M. Zhang, Research and development of Inconel 718 type superalloy Materials Science, 539-543: 262-269 (2007)

2. W.-D. Cao, R. Kennedy, New developments in wrought 718-type superalloys, Acta Metallurgica, 18: 39-46 (2005)

3. H. Yuan, W.C. Liu, Effect of the delta phase on the hot deformation behavior of Inconel 718, Materials Science and Engineering:A, 408: 281-289 (2005)

4. W.-D. Cao, R. Kennedy, Role of chemistry in 718-type alloys - Allvac 718Plus alloy development, Superalloys TMS, 91-99 (2004) 
5. R. L. Kennedy, Allvac718Plus, Superalloy for the next forty years, Superalloys 718, 625, 706 and Derivatives TMS, (2005)

6. X. Xie et al., Structure stability study on an newly developed Nickel-Base superalloyAllvac 718Plus, Superalloys 718, 625, 706 and Derivatives TMS, 179-191 (2005)

7. X. Xie et al., TTT diagram of a newly developed Nickel-Base Superalloy - Allvac 718Plus Superalloys 718, 625, 706 and Derivatives TMS, 193-202 (2005)

8. E. Pickering et al., Grain-boundary precipitation in Allvac 718Plus, Acta Materialia, 60: 2757-2769 (2012)

9. S. Olovsjö, A. Wretland and G. Sjöberg, The effect of grain size and hardness of Waspaloy on the wear of cemented carbide tools, Journal Advanced Manufacture Technology, 50: 907-915 (2010)

10. Y. Gu et al., New Ni-Co-base disk superalloys with higher strength and creep resistance, Acta Materialia, 55: 815-818 (2006)

11. Y. Gu et al., Development of Ni-Co base alloys for high-temperature disk applications, Superalloys TMS 2008, 53-61 (2008)

12. R. Cozar, A. Pineau, Morphology of $\gamma^{\prime}$ and $\gamma^{\prime \prime}$ precipitates and thermal stability of Inconel 718 type alloys, Metallurgical Transactions, 4: 47-59 (1973)

13. E. Andrieu, R. Cozar, A. Pineau, Effect of environment and microstructure on the high temperature behavior of Alloy 718, Superalloy 718-Metallurgy and Application, 241-256 (1989)

14. R. Cozar, A. Pineau, Influence of the $\mathrm{Co} / \mathrm{Ni}$ Ratio on the $\gamma^{\prime}$ and $\gamma^{\prime \prime}$ precipitation in Fe-NiCo-Ta alloys, Metallurgical Transactions, 5: 2471-2472 (1974)

15. D. Furrer, H. Fecht, $\gamma^{\prime}$ formation in superalloy U720Li, Scripta Materialia, 40: 1215-1220 (1999)

16. T. Fedorova et al., Development of a new 718-type Ni-Co superalloy family for high temperature applications at $750^{\circ} \mathrm{C}$, (Paper will be presented at the Eurosuperalloys conference 2014) 